\title{
PSYCHOLOGICAL ASPECTS OF DEVELOPMENT OF COORDINATION BETWEEN 6-8 YEARS OLD CHILDREN'S MUSICAL HEARING AND VOCAL APPARATUS
}

\author{
Jelena Davidova \\ Daugavpils University, Latvia \\ Galina Zavadska \\ Daugavpils University, Latvia \\ Asta Rauduvaite \\ Lithuanian University of Educational Sciences, Lithuania \\ Ming-Jen Chuang \\ National Taichung University of Education, Taiwan, Province of China
}

\begin{abstract}
In the present article, the psychological aspects of the development and process of coordination between 6-8 years old children's musical hearing and vocal apparatus are considered, among which an important role is played by such cognitive processes as music perception, representation of musical hearing, musical thinking, musical memory and selfcontrol. This research aims at studying the psychological aspects of the process of coordination of musical hearing and vocal apparatus between 6-8 years old children.
\end{abstract}

Keywords: coordination between musical hearing and vocal apparatus, music perception, representations of musical hearing, musical thinking, musical memory, self-control.

\section{Introduction}

Singing is a complex sound making process, in which coordination between hearing and voice is of great importance, that is, the interaction between singing intonation (non-false sounding) and auditory, muscular sensations. Singing has a profound effect on the emotional sphere and on the child's mental development; it improves his/her basic mental functions and is directly related to his/her physiological development. It broadens the children's range of interests, increases their level of knowledge about the life around and the phenomena of nature. Therefore, developing the children's singing ability is a powerful means of education and development.

Research, in correlation with hearing and voice is carried out in different aspects, such as: peculiarities of developing children's voice (Glaze, Bless, 
Milenkovic, \& Susser, 1988; McPherson, 2006, Pribujsiene, Uloza, \& Kardisiene, 2011; Орлова, Эстрова, \& Жалмыкова, 2013); vocal setting and singing skills (Hirano, Kurita, \& Nakashima, 1983; Gordon, 1985; Apfelstadt, 1988: Russell, 1997; Thurman \& Welch, 2000); nature and health of singing voice (Harris, Harris et al., 1998; Sataloff, 1998; Greene \& Mathieson, 2001). There are several researches, where issues such as music perception (Seashore, 1967; Hallam, Gross, \& Thaut, 2009), musical memory (Goetze, Cooper, \& Brown, 1990; Finney \& Palmer, 2003), musical thinking (Sloboda, 1988; Gardner, 1999; Deutsch, 2013), self-control (Sundberg, 1987; Russell, 2003) are considered.

However, at the moment, conflicting ideas abound, relating to the interrelationship and interdependence in developing the child's voice as well as the child's mental processes. This is explained primarily due to the complexity of the interrelationship between the level of the child's mental development and his/her musical abilities. Therefore, a comprehensive study of the psychological aspect of children's voice is necessary, in order to understand many theoretical problems associated with the vocal pedagogy, as well as proffering a successful solution for solving the practical problems of coordination between sound making of children's singing voice and musical hearing.

This research aims at studying the psychological aspects of the process of coordination of musical hearing and vocal apparatus between 6-8 years old children.

The research method entails analysis of some theoretical conceptions in the context of the present research.

\section{Musical and Auditory Representations}

Developing coordination between musical hearing and vocal apparatus is a very complex process, which involves the participation of cognitive processes such as representations of musical hearing and its perception, musical thinking, musical memory and self-control. In turn, these cognitive processes are directly related to the level of development of children's musical abilities.

B. Teplov (Теплов, 1947) considers the ability of auditory representations of the musical material to be one of the main components of musical hearing. Representation - a mental process, the formation without which it is impossible to master the three basic ways of getting familiar with the world: cognition, comprehension, transformation. This ability underlies the reproduction of melody with the help of voice or picking it up by hearing on an instrument; it is a necessary prerequisite for a harmonic perception of polyphonic music. Musical and auditory notions as a constituent of the musical abilities - that is, the ability to freely use the auditory representations, which reflect the movement of the pitch of the melody line, expressed as the ability to memorise a musical composition and 
reproduce it from memory.

At the modern stage of development of the music pedagogy, the musical and auditory representations in the pedagogical process are increasingly being considered as the foundation, which has a rich potential beneficial for the child's development. In recent scientific research (Roberts, 1986; Banton, 1995; Korenman \& Peynircioglu, 2007), the tendency to interpret the musical and auditory representations as a set of properties of an individual's personality, which have emerged and developed in the process of formation, creation and assimilation of the musical material, has been outlined.

Musical and auditory representations usually are arising spontaneously in more or less close contact with the musical phenomenon. As emphasised by B. Teplov (Теплов, 1947), the physiological foundation for the musical and auditory representations are the presence of "traces" in the cerebral cortex when sound sensations are being perceived. For musically gifted people, whose musical hearing has formed sufficiently these notions is being developed faster, more accurately and solidly. On the contrary, weaknesses, lack of development of the functions of inner hearing naturally are result in paleness, indistinctness and fragmentation of the notion. In order to reproduce music with the help of voice or on a musical instrument, it is necessary to have an auditory representation of how the sounds of music are moving - up, down, slowly, jumping or repeatedly. In order to reproduce a melody by hearing, it has to be remembered. Therefore, the musical and auditory representations have a close interrelation with memory and imagination (Finney \& Palmer, 2003).

A child's intellectual development is impossible without the formation of representations. A lack of clear representation about the external objects affects the child's perception, but a lack of representations about the existing links between objects, aggravates the thinking process. No matter how simple the activities are (listening to a song, singing it, dancing to it), they are all musical and practical activities. Therefore, representations are formed and developed by frequent repetitions of different activities.

Mastering singing with children, takes place gradually as a result of "countless tries", during which, on one hand, the ability of using vocal apparatus is created, and on the other hand, musical and auditory representations are formed (Теплов, 1947). Psychologists S. Trehub, B. Schneider, B. Morrongiello and L. Thorpe (1988) noted that children's auditory sensitivity appears at a young age.

From the first months a normally developing child responds to the nature of music with the so-called complex of revival, rejoices or calms down. By the end of the first year of baby's life, when listening to the singing of an adult, it adjusts to his/her intonation by humming or babbling. During the second year of life a child distinguishes between high and low sounds, loud and quiet sounds and even the timbre (plays glockenspiel or drums). Gradually, by imitating an adult, a child 
repeats after him/her the end of a musical phrase of a song. He/she is able to perform simple movements: clapping, stamping, and turning around to the sound of music. Over the next few years, some children can accurately reproduce a simple melody; by the fourth year of life a child can sing simple short songs.

At the age of five a child is able to determine that there can be different kinds of music (cheerful, joyful, relaxing) and sounds (high, low, loud, quiet); can accurately determine on what musical instrument the composition is being played. Children's vocal and auditory coordination is well-developed. At the age of six, children can already describe a composition independently, and they are able to perceive a musical image as a whole. During the process of growing up, a child can develop the ability of musical expressiveness, rhythmic movements, and most importantly - to listen to and perform music. It contributes to the development of musicality and hearing, and mastering the necessary skills required to prepare for singing from music.

The age of children ranging from 6-8 years is the foundation laying period for music and auditory representations, as well as basic attitudes towards the musical material. Generalisation of musical and auditory representations becomes the foundation for developing children's singing skills.

\section{Music Perception}

The age between 6-8 years for a child is characterised by educators and psychologists as a special period in the development of his/her perception. Perception is a non-mechanical, mirror image made by the human brain of the thing he/she sees in front of him/her, or what he/she hears. Perception is always an active process, an activity: it is the first step of the thought process; therefore, it precedes and accompanies all kinds of musical activities (Schacter, Gilbert, \& Wegner, 2011). This is the period when an active formation important for learning and development of children's behavioural traits, activities related to the intellectual and emotional sphere, take place. Development of children at this age is characterised by the emergence of complex forms of cognitive activity.

In the area of perception, the development goes from the simplest distinctions made by children, ranging from the brightest of colours, shapes and sounds to a more active awareness of beautiful harmonic combinations, to the differentiation of pitch and rhythmic relationships in music, the nuances of colours, variety of shapes, and poetic harmonies. For such a child, an emotional type of assessment of what is happening is predominantly characteristic rather than an intellectual and rational type (Jones, Fay , \& Popper, 2010).

Research carried out by psychologists (Esposito \& Serio, 2007) suggests that by the time they start school, the perception of the child would have attained a higher level. However, it is not yet sufficiently differentiated for seven years old 
children: it does not have a purposeful character, and is often involuntary (unintentional perception). Therefore, in combination with the same features of the attention, the child's perception attracts brightness, mobility of music, and imagery. Furthermore, a characteristic feature of his/her perception is a pronounced emotionality. However, for the formation of an intentional perception, children should be taught ways and analysis of the perceivable musical material, highlighting its main principles and elements, and establishing the links between them.

Music perception as defined by J. Nazaykinsky (Назайкинский, 1972) includes the ability to experience the mood and feelings, expressed by the composer in a musical composition, and derive an aesthetic pleasure from it. Perception of music takes place when a child is still young and cannot engage in other kinds of musical activity, and when he/she has not yet gotten to the stage of perceiving other kinds of art. Music perception is the leading form of musical activity which cuts across all age groups of children.

Children between 6-8-years can distinguish not only the overall emotional colouring of music, but also its expressive intonations. Children can identify expressive accents, the nature of the melody, accompaniment. Also, they have an idea that the character of the music is transferred to a certain combination of expressive means.

\section{Musical Thinking}

Thinking asa process of cognitive activity is characterized by generalizing and mediating reflection of the reality. An obligatory condition for developing musical thinking is the acquisition of knowledge. The basis of thinking is the formation and improvement of mental actions. Activity is the original form of thinking (Рубинштейн, 1999; Выготский, 1999).

Musical thinking is related to the skill of (a) determining the meaning and mood of the music, as well as the development of the musical image; (b) comprehending the idea as a whole; (c) understanding the expressiveness of musical speech; (d) highlighting the different musical means of transmitting the contents. V. Podurovsky and N. Suslova (Подуровский? Суслова, 2001) defined musical thinking as the real process taking place during intoning, where the musical language play a special role, which is in a sense a sound system subjected to certain rules (standards).

In psychological studies (Barret, 1997; Veloso, 2010) thinking is a real mental activity, which attaches a person to the art of music, and learning the meaning of the values which it contains. Musical thinking is the child's awareness of the expressiveness of the musical image on the basis of distinguishing between musical intonations, their changes and development. It is formed and developed 
in support of musical experience gained by children in different kinds of musical activity, and knowledge about different epochs and styles of music.

Psychology of thinking distinguishes between the following basic operations: definition, synthesis, comparison and distinction, analysis, abstracted grouping and classification, judgment, and reasoning (Выготский, 1999). Most of them are present in the process of musical thinking in a more or less specific way. A particular fluidity and the irreversibility of the musical text, necessitates continuous structuring of the auditory stream. Musical cognition necessarily involves comparing what sounds at the moment to previously heard sounds: a) comparison of sounds according to their height and length gives an idea of the tonal and rhythmical organisation of intonation and motives; b) comparison of motifs and phrases allows to perceive the magnitude of the structure; c) comparison of parts and sections lead to reflection on the form and type of development; d) comparison of the given composition with others brings out the genre and stylistic features.

Child's thinking, his/her psychological experience, emotional, motivational and other spheres of the personality are different from the psyche of an adult. For a variety of psychological parameters, as an optimal beginning for educational guidance and for the development of musical thinking, the primary school age can be recognized (including 6-8 years) (Gordon, 1990; Выготский, 1999; Feierabend, 2015). It is meant for the youngest school age children when the learning activity becomes the leading one. At this age, a whole complex of necessary, psychological preconditions for the formation of musical thinking is being developed: sensory-perceptual activity provides a rich auditory perception; motor activity allows you to live through, "work out" the movements of different types of music; emotionally expressive activity is manifested in the emotional experience of music; intellectual and volitional activity contributes to the process of musical thinking.

\section{Musical Memory}

Memory is a psychic function and a way of mental activity, which ensures the acquisition of information, remembrance and reproduction (McLeod, 2007). Memory is a complex process of transforming sensory and perceptual material obtained with the sense organs; it is the organisation, saving and performance of what was experienced by the individual previously. It is actively turned on in all the manifestations of the mind: attention, feelings, perception, representation, thinking, imagination; it is an integral component of complex structures of personality such as temperament, character and abilities. As a result of the organic unification from previous experience with any action and any activity, memory itself becomes an active guiding force for these processes, in turn, becoming their 
structural component (Рубинштейн, 1999).

Researchers of musical memory (Wallace, Siddiqua, \& Harun-ar-Rashid, 1994; Wilson \& Saling, 2008) noted that musical memory is a cooperation of different kinds of memory, which every person has, that is, it is the memory of the ear, eye, touch and movement. According to our sense organs, five types of figurative memory are distinguished: auditory, visual, olfactory, gustatory, and tactile. Thus, musical memory is a synthesis of visual, auditory and tactile type of memory.

Musical memory is one of the leading musical abilities. During the sensible perception of music, its performance, composition, and study of music theory, the development of musical memory takes place (Seashore, 1967).

At the age of five, the majority of children have a fairly high level of musical memory. Children recognize songs previously showed them by their melody, which has become carriers of independent information for them -a direct link to the verbal text. Children's musical memory develops in parallel with the actual perception of music, its emancipation, and withdrawal from the syncretic forms. It is a general principle, an activity which applies to the majority of 6-8 years old children. K. Tarasova (Тарасова, 1988) also noted that the formation of identifying memory during ontogeny precedes the formation of reproductive memory. With regard to the individual differences between the children in terms of the development of this ability, and according to its development and qualitative indicators, these differences remain stable throughout the period of childhood.

\section{Children's Self-control in the Process of Singing}

Self-control is understood to mean the reflection and evaluation of own actions by the subject. Self-control is an important skill for all children in the process of learning: it refers to control over own actions, it also means that the child knows what are right and not right (Eckman, 1998).

While a child sings, different types of self-control are involved in the complex organisation of the work of his/her vocal apparatus: auditory, visual, kinaesthetic, and so on. When the voice is being trained, it is necessary to also teach how to coordinate and strengthen muscles in the larynx by doing special exercises in order to sing beautifully. When forming intoning self-control, the hearing analyser, which is one of the main "controllers" during singing, is a determinant and is of importance. Violation, weakening of auditory self-control leads to an incorrect organisation of musical intonation. Children need to learn at the level sub consciousness, how to control the activity of the vocal apparatus during singing, in order to (a) make vocal cords to contract when the high notes are being sung and (b) the inner muscles would stay relaxed (Hennessy, 1998). 


\section{Psychological Reasonsfor 6-8 Years Old Children's Imprecise Intonation}

There are several difficulties in developing children's singing culture. The main among them, which is the most acute, is imprecise intonation (Davidova, Zavadska, Šeršnova, Rauduvaite, \& Chuang, 2015).

Based on the research by J. Shaw (2013), the following groups of reasons for children's imprecise intonation can be distinguished: a) physiological (accessing the singing voice, respiration, vocal coordination, kinaesthetic awareness, vocal health); b) psychological (pitch perception, tonal memory, emotionality); c) organic (disease, malformation, delayed maturation); d) influence of the surrounding environment (musical exposure, singing models).

The second group of reasons for imprecise intonation is related to the child's psychological state and development. A reason for imprecise intonation can be different varies with individual and with every child. However, most often, there are children who sing out of tune because of the unstable focus, as well as shy children, who are not accustomed to show their skills to their peers or the teacher.

Also, the reason for too low singing or "humming" can be internal restrain or excessive exposure of the internal motions to gravity (McAllister \& Sjölande, 2013). Researchers believe that children in younger classes (which also include 6-8 years old children) need to develop active hearing. Thus, the psychological reasons for imprecise intonation include inattention, shyness and internal restraint.

\section{Conclusion}

1. The psychological development of 6-8 years old children is extremely important for the training and development of the singing voice. As a result of the child's singing activity, the perception, memory, thinking, imagination and feelings are being improved upon, knowledge is acquired, new needs, interests and emotions appear, and skills are being developed.

2. Music perception and representations of musical hearing have a great influence on the development of a child's musical hearing and vocal apparatus. They are directly related to the intonation of the music material and performance of muscles of the vocal apparatus. Musical thinking is developed through the sense and perception of music, which ensures the development of children's creativity and logical reasoning. The musical thinking of 6-8 years old children lacks the conscious element which is a distinction between the similar and the dissimilar. An analysis of the sounding information and the synthesis of an ideal expression for the sounding phenomenon are carried out unconsciously. Musical memory is a complex set of different kinds of memory; it is universal and is expressed 
while imitating a known melody, during the process of children playing music or singing. During the process of intonation, children learn to listen to themselves and learn to control the precision of intonation with the help of hearing. Self-control helps to regulate the process of phonation with the help of sensations - hearing, muscular, resonator (vibrating).

3. The process of phonation for children is significantly different from the singing of adults. Awareness and knowledge of the child's psychological features can help teachers-vocalists in performing a correct vocal training, coordination between hearing and muscular sensations of the vocal apparatus, and the development of children's singing skills.

\section{References}

Apfelstadt, A. (1988). What makes children sing well? Research in Music Education, 2 (12), 27-32.

Banton, L. (1995). The role of visual and auditory feedback during the sight-reading of music. Psychology of Music, 23, 3-16.

Barret, M. (1997). Invented notations: A view of young children's musical thinking. Research Studies in Music Education, 8, 2-14.

Davidova, J., Zavadska, G., Rauduvaite, A., \& Chuang, M.-J. (2015). Physiological Features of Developing 6-8 -year-old Children's Vocal Apparatus. Problems in Music Pedagogy, 14, (1), 119-129.

Deutsch, D. (2013). The processing of pitch combinations. In D. Deutsch (Ed.), The Psychology of Music. San Diego: Elsevier, 249-325.

Eckman, L. (1998). Self-control Skills for Children. Helping children at home and school: Handouts from your school psychologist. Retrieved 16.04.2015 from http://www.nasponline.org/resources/handouts/behavior\%20template.pdf

Esposito, A., \& Serio, M. (2007). Children's perception of musical emotional expressions. In Verbal and Nonverbal Communication Behaviours.Berlin: Springer Berlin Heidelberg, 51-64.

Feierabend, J. (2015). Music and Intelligence in the Early Years. Retrieved 16.04.2015 from https://www.giamusic.com/music education/feier_musicandintelligence.cfm

Finney, S., \& Palmer, C. (2003). Auditory feedback and memory for music performance: Sound evidence for an encoding effect. Memory \& Cognition, 31 (1), 51-64.

Gardner, H. (1999). Intelligence Reframed. New York: Basic Books.

Glaze, L., Bless, D., Milenkovic, P., \& Susser, R. (1988). Acoustic characteristics of children's voice. Journal of Voice, 2, (4), 312-319.

Goetze, M., Cooper, N., \& Brown, C. (1990). Resentresearch on singing in the general music classroom. In D. Deutsch (Ed.), The Psychology of Music. San Diego: Academic Press Series in Cognition and Perception.

Gordon, D. S. (1985). A survey of literature and practice in assisting the pitch-defective singer in the elementary school. In Pennsylvania Music Educators Association: Bulletin of Research in Music Education, 16, 11-18.

Gordon, E. (1990). Learning Sequences in Music: Skill, content, and patterns. Chicago: G.I.A. Greene, M., \& Mathieson, L. (2001). The Voice and its Disorders. Philadelphia: Whurr. 
Jelena Davidova, Galina Zavadska, Asta Rauduvaite, Ming-Jen Chuang. Psychological Aspects of Development of Coordination Between 6-8 Years Old Children's Musical Hearing and Vocal Apparatus

Hallam, S., Gross, I., \& Thaut, M. (2009). The Oxford Handbook of Music Psychology. Oxford, UK: Oxford University Press.

Harris, T., Harris, S. et al. (1998). Teaching singing to children and young adults. The Voice Clinic Handbook. London: Whurr.

Hennessy, S. (1998). Coordinating Music across the Primary School. London: Routledge.

Hirano, M., Kurita, S., \& Nakashima, T. (1983). Growth, development and aging of human vocal fold. In D. M. Bless, \& J. W. Abbs (Eds.), Vocal Fold Physiology. San Diego: College Hill Press, 22-43.

Jones, R., Fay, R., \& Popper, A. (Eds.). (2010). Music Perception. New York: Springer.

Korenman, L., \& Peyhircioglu, Z. (2007). Individual differences in learning and remembering music: Auditory versus visual presentation. Journal of Research in Music Education, 55, (1), 48-64.

McLeod, S. (2007). Stages of Memory - Encoding Storage and Retrieval. Retrieved 21.04.2015 from http://www.simplypsychology.org/memory.html

McAllister, A., \& Sjölande, P. (2013). Children's voice and voice disorders. Seminars in Speech and Language, 34 (2), 71-79. Retrieved 18.04.2015 fromhttp://dx.doi.org/10.1055/s00331342978

McPherson, G. (Ed). (2006). The Child as Musician: A handbook of musical development. Oxford: Oxford University Press.

Pribujsiene, R., Uloza, V., \& Kardisiene, V. (2011). Voice characteristics of children aged between 6 and 13 years: Impact of age, gender, and vocal training. Unbound Medline, 36

(4), 150-155. Retrieved 12.04.2015 from http://informahealthcare.com/doi/abs/ $10.3109 / 14015439.2011 .569756$

Roberts, L. A. (1986). Modality and suffix effects in memory for melodic and harmonic musical materials. Cognitive Psychology, 18, 123-157.

Russell, J. (1997). A place for every voice: The role of culture in the development of singing expertise. Journal of Aesthetic Education, 31 (4), 95-109.

Russell, J. (2003). Singing "practice" and the importance of community. Canadian Music Educator, 45 (2), 15-19.

Sataloff, R. T. (1998). Vocal Health and Pedagogy. San Diego: Singular Publishing.

Schacter, D., Gilbert, D., \& Wegner, D. (2011). Psychology. Retrieved 14.04.2015 fromhttp://www.macmillanhighered.com/Catalog/product/psychology-secondeditionschacter

Seashore, C. E. (1967). Psychology of Music. New York: Dover Publications.

Shaw, J. (2013). Strategies for working with inaccurate singers. Illinois Music Education Conference Peoria, Illinois. Retrieved 11.04.2015 from http://www.ilmea.org/ site_media/filer_public/2013/01/11/shaw.pdf

Sloboda, J. A. (1988). The Musical Mind: The cognitive psychology of music. Oxford: Oxford University Press.

Smith, R. (1963). The effect of group vocal training on the singing ability of nursery school children. Journal of Research in Music Education, (11), 137-141.

Sundberg, J. (1987). The Science of the Singing Voice. Illinois: Northern Illinois University Press.

Thurman, L., \& Welch, G. (Eds). (2000). Body Mind and Voice: Foundations of voice education. Collegeville, MN: The Voice Care Network.

Trehub, S., Schneider, B., Morrongiello, B., \& Thorpe, L. (1988). Auditory sensitivity in school-age children. Journal of Experimental Child Psychology, 46 (2), 273-285. 
Veloso, A. (2010). Analyzing the Development of Children's Musical Thinking through Music Composition Activities. Retrieved 16.04.2015 from http://www.academia.edu/376169/ Analyzing_the_development_of_Children_s_Musical_Thinking_through_music_compo sition_activities

Wallace, W., Siddiqua, N., \& Harun-ar-Rashid, A. (1994). Memory for music: Effects of melody on recall of text. Journal of Experimental Psychology: Learning, Memory, and Cognition, 20 (6), 1471-1485.

Wilson, S., \& Saling, M. (2008). Contributions of the right and left medial temporal lobes to music memory: Evidence from melodic learning difficulties. Music Perception, 25 (4), 303-314.

Выготский, Л. (1999). Мышление и речь [Thinking and Speech]. Москва: Лабиринт (in Russian).

Назайкинский, E. (1972). О психологии музыкального восприятия [On Psychology of Music Perception]. Москва: Музыка (in Russian).

Орлова, А., Эстрова, П., \& Калмыкова, А. (2013). Особенности развития детского голоса в онтогенезе [Features of developing children's voice during ontogeny]. Специальное образование, (4), 92-104 (in Russian).

Подуровский, В., \& Суслова, Н. (2001). Психологическая коррекция музыкальнопедагогической деятельности [Psychological Correction of Musical and Educating Activity]. Москва: Владос (in Russian).

Рубинштейн, С. (1999). Основы общей психологии [Basics of General Psychology]. Москва: Питер (in Russian).

Тарасова, К. (1988). Онтогенез музыкальных способностей [Ontogeny of Musical Abilities]. Москва: Педагогика (in Russian).

Теплов, Б. (1947). Психология музыкиимузыкальных способностей [Psychology of the Music and Musical Abilities]. Москва, Ленинград (in Russian). 